ks. Łukasz Marczak

(1) https://orcid.org/0000-0003-1553-1747

Uniwersytet Papieski Jana Pawła II w Krakowie

\title{
Wzrost świadomości osoby w aplikacji zasady zrównoważonego rozwoju. Rodzina jako zasób społeczny
}

https://doi.org./10.15633/9788374389839.08

W naukach socjologicznych wciąż występuje potrzeba objaśniania zasady zrównoważonego rozwoju pod względem tworzenia uwarunkowań społeczno-gospodarczych i środowiskowych, w których wyszczególnione zostałyby czynniki wzmacniające wartość rodziny. Zazwyczaj podkreśla się znaczenie dymensji środowiskowej i ekonomicznej zrównoważonego rozwoju, marginalizując czynniki rozwoju społecznego ze względu na pilność działań na rzecz środowiska. Przy akcentowaniu celów służących konsekwencjom związanym ze zmianami klimatu wydaje się wzrastać świadomość ekologiczna, która w nurtach etyk nieantropocentrycznych umniejsza wartość godności osoby ludzkiej'.

Tendencji specjalizacji i profesjonalizacji pomocy społecznej na gruncie nauk socjologicznych sprzyja pojawianie się nowych zawodów, np. facylitatora. Ich sprzężenie $\mathrm{z}$ familiologią i instytucjami pomocy społecznej stanie się korzystne zarówno dla poszerzenia kompetencji interpersonalnych i autokreacyjnych pracowników świadczących pomoc społeczną, jak i dla samej rodziny i społeczeństwa, które w związku z realizowaną polityką klimatyczną w świadomości społecznej przeżywają swoistą reorientację na kwestie środowiskowe. Nowe principium społeczne dotyczy również obszarów nauk społecznych, w tym pracy socjalnej, w której wiedza ta mo-

1 A. Ganowicz-Bączyk, Etyka środowiskowa, w: Etyka. Część II. Filozoficzna etyka życia spetnionego, red. S. Janeczek, A. Starościc, Lublin 2016, s. 181-2o8. 
głaby znaleźć swoje zastosowanie ${ }^{2}$. Aplikacja zasady zrównoważonego rozwoju w zakresach oddziaływania familiologii ma na celu udoskonalenie uwarunkowań życia społecznego poprzez stawianie w centrum sieci społecznych powiązań nie tylko człowieka, ale także rodzinę jako podstawową grupę społeczną w jej otoczeniu środowiskowym ${ }^{3}$. Zatem dla realizacji zrównoważonego rozwoju kluczowe będzie podejmowanie zaangażowania, w którym można aplikować zasadę etyczno-społeczną stojącą na straży wartości osoby ludzkiej. Takie stanowisko potwierdza Wanda Nagórny, zauważając potrzebę włączenia kapitału ludzkiego do równoczesnej analizy kapitału ekonomicznego i przyrodniczego ${ }^{4}$. Oznacza to ujmowanie wartości rodziny w taki sposób, by wzrastał stopień świadomości etycznej: kim jest integralnie rozumiany człowiek i jaka jest różnica między nim a otoczeniem środowiskowym. W zakresie komponentu społecznego zasady rozwoju zrównoważonego komunikowanie wartości rodziny w systemach normatywnych jest równie ważnym działaniem jak kształtowanie świadomości ekologicznej. Nabieranie cech obywatelskich przez społeczeństwo bywa stymulowane przez świadomość ekologiczną, której służą działania edukacyjne i informacyjne ${ }^{5}$.

W opracowaniu ukaże się najpierw zasadę zrównoważonego rozwoju w kontekście występowania etyk nieantropocentrycznych. Następnie wskaże się pożądany cel aplikacji tego principium etyczno-społecznego: wzrost świadomości osobowej w kontekście realizacji celów zrównoważonego rozwoju. Aby uwydatnić komponent społeczny zasady zrównoważonego rozwoju, przedstawi się działania mające wzmocnić rodzinę w zakresie edukacyjnym i kształtowania świadomości społecznej ${ }^{6}$.

2 P.S. Czarnecki, Praca socjalna, Warszawa 2013, s. 205.

3 M. Vogt, Prinzip Nachhaltigkeit. Ein Entwurf aus theologisch-ethischer Perspektive, München 2009, s. 347-356.

4 W. Nagórny, Polityka społeczna a zrównoważony rozwój, „Prace Naukowe AJD. Pragmata Tes Oikonomias" (2011) nr 5, s. 145.

5 M. Góra, Środowisko życia człowieka i jego rozwój w kontekście politycznym i środowiskowym, „Studia Socialia Cracoviensia” 5 (2013) nr 1, s. 169.

6 W. Nagórny, Polityka społeczna a zrównoważony rozwój, dz. cyt., s. 143. 


\section{Zasada zrównoważonego rozwoju versus etyki nieantropocentryczne}

W wyniku wzrostu zainteresowania nowymi nurtami filozofii, o charakterze ekologicznym, wykreowały się nurty etyk środowiskowych, w których został zakłócony naturalny porządek pomiędzy bytami stworzonymi. Status osoby ludzkiej uległ osłabieniu ${ }^{7}$. Ponowoczesny i posthumanistyczny świat wartości odsłonił powolny zanik stabilnego fundamentu orientacji personalistycznej, co objawia się wzrostem ryzyka wykluczenia społeczno-ekonomicznego wskutek szeroko pojętych konsekwencji „błędu antropologicznego" ${ }^{8}$. Sens życia tłumaczony jest i uświadamiany w nurtach postmodernistycznej niestabilności aksjonormatywnej ${ }^{9}$. Zagubienie personalistycznego statusu osoby ludzkiej odbija się ze zwielokrotnioną siłą i częstotliwością w sieciowo zarządzanych społeczeństwach, poddanych oddziaływaniu nurtów filozofii ekologicznej.

Zasada zrównoważonego rozwoju wyraża jakościowe rozszerzenie dobra wspólnego o właściwe ujęcie złożoności systemów społecznych z systemami gospodarczymi i ekosystemami ${ }^{10}$. Wkomponowanie kategorii „zrównoważony rozwój” w systematykę zasad etyczno-społecznych, a może bardziej wyłonienie nowej zasady etyczno-społecznej, przywraca właściwy, należny status osobie ludzkiej i w nurcie etyk środowiskowych opowiada się za antropocentryzmem umiarkowanym. Aplikacja zasady zrównoważonego rozwoju tworzy więc uwarunkowania społeczno-gospodarcze i kulturowe, które służą człowiekowi do tego, aby pełniej i szybciej osiągał swoją doskonałośćc ${ }^{11}$. Rodzina pełni w tym zakresie wiele ważnych, bo fundamentalnych funkcji socjalizacyjnych. W korelacji z zasadą pomocniczości zasada zrównoważonego rozwoju nabiera instytucjonalnej

7 Por.Zrównoważony rozwój-wyzwania globalne. Podręcznik dla uczestników studiów doktoranckich, red. P. Trzepacz, Kraków 2012, s. 37, 40-41.

8 M. Dróżdż, Wposzukiwaniu antropologicznych kontekstów wykluczenia społecznego. Inspiracje personalistyczne, „Studia Socialia Cracoviensia” 6 (2014), nr 2, s. 88.

9 P. Prüfer, Idea rozwoju ludzkiego. Myśl społeczna Kościoła w stużbie rozwoju każdego człowieka i wszystkich ludzi, w: Wobec Boga i człowieka, red. E. Piotrowski, Zielona Góra-Gorzów Wlkp. 2006, s. 202.

10 S. Fel, Ł. Marczak, Powstanie i status zasady zrównoważonego rozwoju, „Roczniki Nauk Społecznych" 44 (2016) nr 2, s. 185-205.

11 W. Piwowarski, Dobro wspólne, w: Stownik katolickiej naukispołecznej, red. W. Piwowarski, Warszawa 1993, s. 41. 
mocy sprawczej, a w duchu solidarności procesy socjalizacyjne mają zapewniać osobie ludzkiej wszechstronny rozwój we wszystkich wymiarach osobowości, także na złożonych płaszczyznach, począwszy od odniesień do życia kulturowego i społecznego, a skończywszy na trendach podkreślających fundament środowiskowy ${ }^{12}$.

Personalistyczne ujęcie zasady zrównoważonego rozwoju ujmowane jest w nurcie personalizmu wertykalnego, wprowadzającego człowieka w świat transcendencji konstytuującej go w niej ${ }^{13}$. Przyjęcie perspektywy personalizmu horyzontalnego może skutkować powrotem do postaw neopogańskich, panteistycznych, odzwierciedlających materialistyczny ateizm, naturalizm czy apersonalizm. Wówczas istnieje ryzyko redukcji człowieka do bytu pozbawionego wymiaru duchowego, co przedstawicielom nurtów filozofii ekologicznej stwarza szansę socjalizacji treści w nurcie etyk środowiskowych o charakterze nieantropocentrycznym. Innego rodzaju reperkusje mogą zaistnieć w przypadku antropocentryzmu szowinistycznego, w którym człowiek uważany jest za wroga z racji jego nieograniczonej możliwości ingerowania w świat stworzony w gospodarowaniu zasobami.

Ideologie zrównoważonego rozwoju wypełnione są różnorodnymi systemami wartości, w których nadinterpretacja sprężenia środowiskowo-społecznego redefiniuje kategorie przypisane wielowiekowej tradycji kultury chrześcijańskiej. Jest to złożony proces, uwydatniający się coraz bardziej w ukształtowanej już kulturze ekologicznej, która skłania się w stronę nurtów: patocentrycznych, fizjocentrycznych, biocentrycznych i ekocentrycznych. Tym mocniej trendy ekologiczne odsłaniają się wraz z ukierunkowaniem gospodarek na cyrkularny model, zastępujący nieograniczoną w gospodarowaniu zasobami środowiska linearność wzrostu. Wobec nowych paradygmatów rozwoju ekologia integralna ukierunkowana jest na umacnianie statusu człowieka traktowanego jako odpowiedzialnego „stróża”, a nie „bezwzględnego pana” ignorującego dynamikę procesów zachodzących w środowisku przyrodniczym ${ }^{14}$. Antropocen-

12 S. Gałkowski, Ekologia - przyroda - ochrona środowiska, w: Stownik katolickiej nauki spotecznej, red. W. Piwowarski, Warszawa 1993, s. 45.

13 I. Dec, Personalizm w filozofii (próba systematyzacji), w: Personalizm polski, red. M. Rusecki, Lublin 2008, s. 303n.

14 J. Mariański, Godność ludzka - wartość ocalona? Studium socjopedagogiczne, Płock 2017, s. 104. 
tryzm umiarkowany nie jest homocentryzmem, który opowiadałby się za nadrzędną pozycją człowieka i utylitarystyczną wartością przyrody. Antropocentryzm umiarkowany jest orientacją osłabiającą nadrzędny status człowieka ze względu na kategorię odpowiedzialności, która w chrześcijańskiej perspektywie za najwyższą wartość w świecie bytów stworzonych afirmuje godność ludzką, życie człowieka i jego rozwój. Rodzina w takim ujęciu pełni doniosłą rolę. Utylitarystyczne traktowanie świata stworzonego ogranicza więc moralna perspektywa człowieka, przed którą w aspekcie środowiskowym otwarta została perspektywa odpowiedzialności za zachowanie równowagi ekosystemowej i międzysystemowej. Ekosystemy muszą zachować swoją specyficzną dynamikę i cykliczność naturalnych procesów, z których ludzkość korzysta jako powiernik dóbr w perspektywie międzypokoleniowej.

Humanizm chrześcijański, którego przejawem jest personalistycznie uzasadniona zasada zrównoważonego rozwoju, stoi w opozycji do ujęć biocentrycznych. Nadają one przyrodzie wartość wewnętrzną i bronią interesów wszystkich gatunków. W ujęcia biocentryczne wpisuje się koncepcja metabolizmu społecznego, która skupia się na regulacji współzależności materialno-energetycznej człowieka ze środowiskiem przyrodniczym. Ze względu na zakres występowania nie można pominąć nurtu patocentrycznego i fizjocentrycznego w etykach środowiskowych związanych z realizacją zrównoważonego rozwoju. Patocentryzm wyraża wysoką wartość każdego życia, stąd ze względu na poczucie cierpienia nie można przedstawicielom poszczególnych gatunków zadawać bólu, a tym bardziej ich zabijać. Człowiek podobnie jak w biocentryźmie i patocentryźmie nie posiada szczególnego statusu pośród istot żywych. Zdaniem Hansa Michaela Baumgartnera przedłużeniem wymienionych ujęć jest fizjocentryzm absolutyzujący związek człowieka z przyrodą i personifikujący środowisko naturalne. Hipostaza przyrody umniejsza status człowieka, odbierając mu naczelną pozycję pośród bytów stworzonych. Innym jeszcze ujęciem etyk nieantropocentrycznych jest ekocentryzm (holicentryzm), który ujmuje całość przyrody ożywionej i nieożywionej w jedność afirmującą każde życie.

Wobec wymienionych ujęć etyk nieantropocentrycznych wraz z ewolucją nadinterpretacji zrównoważonego rozwoju pod względem zachowania ekosystemów, zwłaszcza w kształtowaniu świadomości ekologicz- 
nej w nurcie mocnego zrównoważonego rozwoju, pojawiały się praktyki neomaltuzjańskie ${ }^{15}$. Niniejszy wywód został poczyniony w celu wskazania znaczenia etyczno-społecznej zasady zrównoważonego rozwoju, po to, by zaznaczyć granice nurtom etyk środowiskowych, które wydają się być płynne i nieostro rozgraniczone, zwłaszcza w związku z realizacją globalnych celów zrównoważonego rozwoju. W procesie poszukiwania balansu między systemami społecznymi, gospodarczymi i ekosystemami nie można zapomnieć o arcyistotnych wartościach dla równowagi systemów społecznych. Rodzina jest podstawowym zasobem dla rozwoju społeczno-gospodarczego i ekologia integralna chroni naczelną pozycję tej fundamentalnej instytucji społecznej w złożonej sieciowej zależności systemów zrównoważonego rozwoju ${ }^{16}$. Międzypokoleniowa organizacja dobra wspólnego wymaga mechanizmów dobrobytu i bezpieczeństwa socjalnego, pośród których rodzina jest spoiwem wartości personalistycznego ładu społecznego.

\section{Wzrost świadomości osobowej w kontekście zasady dobra wspólnego}

Uwarunkowania rodziny ujmowanej jako zasób społeczny są znaczącym czynnikiem wpływającym na kształtowanie się tożsamości społecznej. $\mathrm{Z}$ drugiej strony wspólnota osób złączona więzami krwi, czyli rodzina, przynależność do niej i lokalnych społeczności organizujących się wokół wielu wartości podstawowych, decyduje o rodzajach tożsamości. W jej kształtowaniu socjolog Stanisław Ossowski zwracał uwagę na treści myślowe typowe dla pewnych środowisk, wyrażające się stosowaniem kategorii językowych, pojęć, obrazów, przekonań i ocen, które stają się mniejszym lub większym spoiwem grup społecznych. W działaniu jednostek świadomość umacnia wzajemna sugestia, podobne przekonania i wiedza, że dzielą je również inni członkowie tej samej grupy ${ }^{17}$.

15 S. Fel, Maltuzjanizm, w: Encyklopedia katolicka, t. XI, Katolicki Uniwersytet Lubelski Jana Pawła II, Lublin 2006, s. 994n.

16 Franciszek, Laudato si', Watykan 2015, nr 155-158.

17 S. Ossowski, Z zagadnień struktury społecznej, w: Dzieła, red. S. Ossowski, t. V, Warszawa 2005, s. 57; Formy świadomości społecznej, red. K. Sztalt, M. Zemło, Lublin 2013, s. 6. 
Wraz z aplikacją zasady zrównoważonego rozwoju wzrasta przekonanie o nieredukowalności i niepodzielności całości psychofizycznej integralnie ujmowanego człowieka. Psychologia humanistyczna stoi na stanowisku, że naturalnym procesem organizmu ludzkiego jest rozwój własnych umiejętności i dążenie do samorealizacji. Wzrost świadomości osobowej jest naturalnym procesem, w którym człowiek odkrywa wsobną zdolność do wartościowa - co bardziej mu służy do jego rozwoju i poszerzania swoich kompetencji zawodowych. Wraz z ukształtowaną hierarchią ważności celów i odpowiednio ograniczoną wolnością człowiek rozwijający się najbardziej poprzez własne działanie wie, co wybrać, a czego unikać w zaspokajaniu potrzeb ludzkich ${ }^{18}$. Psychologia humanistyczna w teorii dezintegracji pozytywnej w ujęciu Kazimierza Dąbrowskiego ujmuje rozwój człowieka jako wychodzenie poza biologiczny cykl życia i przekraczanie granic natury rozumianej jako złożoność biologiczno-psychiczna. Rozwój ten dokonuje się w sferze psychiki człowieka, którego status zakreśla się w nurcie personalizmu wertykalnego. Aplikacja zasady zrównoważonego rozwoju dotyczy więc systemów społecznych, gospodarczych i ekosystemów, jednak nie można zapomnieć, że złożoność psychosomatyczna człowieka również podlega swoistym prawom na drodze ku osiąganiu dojrzałości osobowej. Integralnie rozumiany człowiek jako jednostka biologiczna jest swoistym ekosystemem poddawanym oddziaływaniu złożoności systemowej, o której mówi usieciowienie w etycznej interpretacji wymogu równoważenia szans rozwojowych w dymensjach zrównoważonego rozwoju ${ }^{19}$. Złożoność psychosomatyczna człowieka ujmowana w nurcie psychologii humanistycznej pozwala dostrzegać nadrzędną wartość osoby ludzkiej, która kierując swoim rozwojem, pokonuje kolejne etapy, kształtując swoją świadomość. Jest to świadomy rozwój człowieka w jego psychosomatycznej dymensji, która przekłada się na jego społeczne zaangażowanie. Wymaga ono właściwych granic wolności, których płynna elastyczność lub nawet brak wystawia życie społeczne na ryzyko chaosu

18 M. Żurko, Świadomość osoby, w: Formy świadomości społecznej, red. K. Sztalt, M. Zemło, Lublin 2013, s. 76.

19 Por. M. Vogt, Retinität: Vernetzung als ethisches Leitprinzip für das Handeln in komplexen Systemzusammenhängen, w: Komplexe adaptive Systeme, red. S. Bornhold, P. H. Feindt Roll, Dettelbach 1996, s. 159-197. 
i większego relatywizmu. Jego przejawem może być nawet podanie w wątpliwość praw człowieka wraz z tymi podstawowymi - do życia i rozwoju.

Wzrost świadomości osobowej w aplikacji zasady zrównoważonego rozwoju komplementarnie złączony jest z tworzeniem uwarunkowań społeczno-gospodarczych, w których człowiek pełniej i szybciej będzie osiągał swoją doskonałość. W realizacji celów wzmacniających rodzinę niezbędne jest sprzężenie zasad pomocniczości i solidarności w organizacji pomocy społecznej i instytucji wzmacniających funkcję rodziny w kulturze, która coraz bardziej ulega nurtom etyk środowiskowych. Wzrost świadomości osobowej w realizacji zrównoważonego rozwoju w pracy socjalnej następuje wraz ze skoordynowaniem wiedzy psychologiczno-pedagogicznej, której zastosowaniu musi sprzyjać znajomość przyjmowanych rozwiązań prawnych na podstawie odpowiednio zdiagnozowanych problemów społecznych ${ }^{20}$. Od rozpoznania trendów godzących w godność ludzką w nieantropocentrycznych ujęciach etyk środowiskowych zależy kierunek działań i wybór szczegółowych zasad etyczno-społecznych, mających na celu wzmocnienie instytucji rodziny w jej otoczeniu społecznym. Słusznie twierdzi Małgorzata Ciczkowska-Giedziuń, że współczesny pracownik socjalny powinien posługiwać się licznymi teoriami wyjaśniającymi zachowanie ludzi i mechanizmy życia społecznego ${ }^{21}$. Wraz z nadinterpretacją zrównoważonego rozwoju w nurtach działań ekologicznych bardziej znaczące staje się zaangażowanie społeczne, w którym pomoc społeczna niesiona na wielu płaszczyznach odgrywa istotną rolę. Wobec realizacji polityk zrównoważonego rozwoju kontekst pomocy społecznej zmienia się, tworząc szansę międzypokoleniowej synergii w życiu społecznym. Wartym uwagi w kształtowaniu świadomości osobowej jest podejście Ewy Kantowicz, która twierdzi, że pracownik socjalny jest nosicielem zmian osobowościowych jednostek, rodzin i społeczeństwa oraz humanistą przygotowującym do kształtowania personalistycznego kontekstu społecznego ${ }^{22}$.

20 Por. M. Ciczkowska-Giedziuń, Ksztatcenie pracowników socjalnych do pracy z rodzina, w: Praca socjalna. Ksztatcenie - dziatanie - konteksty, red. A. Kanios, M. Czechowska-Bieluga, Kraków 2010, s. 76.

21 M. Ciczkowska-Giedziuń, Ksztatcenie pracowników socjalnych do pracyz rodzina, dz. cyt., s. 77.

22 E. Kantowicz, Elementy teorii i praktyki pracy socjalnej, Olsztyn 2001, s. 341. 


\section{Społeczny komponent zasady zrównoważonego rozwoju: rodzina jako zasób społeczny w realizacji polityki społecznej}

Z punktu widzenia polityki społecznej i familiologii społeczny komponent zrównoważonego rozwoju sprowadza się do tworzenia warunków wsparcia rodziny w taki sposób, aby w tej grupie społecznej były realizowane jej podstawowe funkcje. Wsparcie instytucji rodziny, zwłaszcza rodzin dotkniętych marginalizacją, umacnia jej wartość ujmowaną jako specyficzny zasób społeczny. W kształtowaniu świadomości społecznej na polu edukacyjnym wyraża się to głównie we wspomaganiu funkcji: legalizacyjno-kontrolnej, socjalizacyjnej i emocjonalno-ekspresyjnej ${ }^{23}$. W odniesieniu do wymienionych funkcji rodziny w kontekście familiologii wskaże się ogólne działania, które z jednej strony są egzemplifikacją wzmacniania wartości rodziny, z drugiej strony otwierają drogę do poszukiwania najbardziej odpowiednich metod pracy na rzecz rodziny w kontekście realizacji celów zrównoważonego rozwoju ${ }^{24}$.

Familiologia jest interdyscyplinarną nauką służącą wzmocnieniu rodziny po uprzednich badaniach okoliczności, które mogłyby negatywnie wpływać na jej kondycję. Z punktu widzenia instytucji pomocowych służących rodzinie istotny jest właściwy dobór mierników, które kompleksowo złączą tę wartość z czynnikami regionalnymi i przestrzennymi. Odbywa się to nie tylko w kontekście optymalnego użytkowania zasobów środowiska, ale także w kontekście dostępności do dóbr i możliwości realizowania planów służących budowaniu świadomości ekologicznej. Doceniając komponent społeczny zrównoważonego rozwoju, wzmocnienie rodziny będzie wyrażać się w działaniach proekologicznych służących dobru rodziny. Przykładem może być tworzenie możliwości dostępu do zasobów środowiska dla ludzi starszych poprzez likwidację barier architektonicznych ${ }^{25}$. W tym celu Ministerstwo Funduszy i Polityki Regionalnej

23 J. Balicki, Rodzina, w: Stownik spoteczny, red. B. Szlachta, Kraków 2004, s. 1118.

24 Por. L. Szot, Praca socjalna w polskim systemie pomocy społecznej, w: Aspekty teoretyczne i praktyczne pracy socjalnej wobec przemian i wyzwań społecznych XXI wieku. Między ksztatceniem a praktyka, t. 2, red. M. Duda, L. Szot, A. Świerczek, Kraków 2017, s. 51-52.

25 Ministerstwo Funduszy i Polityki Regionalne, Fundusz Dostępności stworzony w celu li- 
stworzyło fundusz dostępności mający na celu likwidację barier architektonicznych poprzez budowę wind. W perspektywie etyki środowiskowej w nurcie personalizmu chrześcijańskiego społeczny komponent zasady zrównoważonego rozwoju sprowadza się do tworzenia uwarunkowań sprzyjających rozwojowi wszystkich członków rodziny, także tych wykluczonych z życia społecznego ze względu na wiek czy chorobę. Zasada zrównoważonego rozwoju służy więc rekonfiguracji wartości i kreowaniu ich właściwej hierarchii w synergii społeczno-środowiskowej. Rodzina również jest wartością, której nie można pomijać w modelowaniu czynników decydujących o postępie i warunkach dobrobytu. Ulgi na rzecz rodziny w transporcie miejskim są również przykładem realizacji celów środowiskowych, w których doceniona jest wartość rodziny (Rodzina plus). Jeszcze innym działaniem jest tworzenie uwarunkowań zrównoważonej turystyki, którą wyrażają działania skupione na organizacji wypoczynku dla osób niepełnosprawnych przy znaczniejszym udostępnieniu szlaków turystycznych. Włączanie działań służących rodzinie w tak złożonych uwarunkowaniach realizacji celów zrównoważonego rozwoju wymaga szeregu działań promocyjno-edukacyjnych, skupionych wokół wartości wynikających z antropologii chrześcijańskiej.

\section{Edukacja o zrównoważonym rozwoju $\mathrm{w}$ perspektywie personalizmu chrześcijańskiego}

W życiu społecznym na polu edukacyjnym wydaje się występować najwięcej przestrzeni do wzmacniania świadomości społecznej o rodzinie. Praca socjalna coraz bardziej doskonaląca się i poddana procesom profesjonalizacji, według Krzysztofa Frysztackiego, „daje możliwości dowiadywania się o zjawiskach i zagadnieniach, które wcześniej nie były w takim stopniu rozpoznawane"26. Problematyka społeczna pracy socjalnej jest złożona i rozwija się dynamicznie. Przez to wciąż wymaga badań i eksploracji najbardziej znaczących działań wpływających na jej specyfikę. W zakresie działań na rzecz rodziny familiologia wspomaga rozwiązy-

kwidacji barier architektonicznych poprzez budowę wind.

26 K. Frysztacki, Wokót pracy socjalnej. Od koncepcji i teorii do kontekstów empiryczno-aplikacyjnych, Kraków 2019, s. 113. 
wanie problemów natury psychologicznej i wychowawczej. Uświadamia o konieczności samorozwoju i podnoszeniu kwalifikacji zawodowych, pomocy w poszukiwaniu pracy zarobkowej i umiejętnym gospodarowaniu dobrem osobistym i wspólnym ${ }^{27}$.

Wypracowanie odpowiedzialnych względem otoczenia środowiskowego postaw życiowych wzmacniających świadomość osoby polega na przyswajaniu norm etycznych i społecznych służących roztropnemu użytkowaniu dóbr wspólnych. Wyuczenie pożądanego zachowania zależy od rodziców, a następnie od instytucji służących rodzinie, m.in. zawodów wspomagających rodzinę, począwszy od pedagogów, przez pracowników socjalnych, asystentów rodziny, a skończywszy na familiologach czy facylitatorach. Zwłaszcza w kontekście realizacji celów służących kształtowaniu postaw prośrodowiskowych zawody służące rodzinie muszą ukierunkowywać wartość rodziny na nurt personalizmu chrześcijańskiego. Przede wszystkim sami rodzice socjalizują dzieci - kształtują ich osobowość, przygotowując je do odpowiedzialnego życia w społeczeństwie i do pełnienia w nim różnorakich funkcji. Wydaje się właściwa uwaga Janusza Balickiego, który twierdzi, że socjalizację potomstwa należy opierać na przekazie wiedzy, wpajaniu wzorców zachowania i związanego z tym określonego systemu wartości, nawet w gospodarowaniu dobrami w zakresie działań rodziny ${ }^{28}$.

Wąskim obszarem, w którym rodzina spełnia przypisane jej funkcje, jest gospodarstwo domowe. Dla społecznej dymensji zasady zrównoważonego rozwoju kluczowa będzie realizacja wartości, która sprowadzałaby się do nabycia umiejętności optymalnego wykorzystywania dostępnych zasobów. Dotyczy to: redukcji zużycia energii, minimalizacji kosztów wskutek nabycia umiejętności oszczędzania, roztropnej konsumpcji, zdrowego stylu życia, a nawet segregacji odpadów. Mankamentem w realizacji zrównoważonego rozwoju jest brak łącznego ujmowania działań, w których wartości społeczne byłyby złączone synergicznie z tymi z zakresu gospodarki i środowiska. Brak tej synergii i balansu międzysystemowego

27 Por. E. Trafiałek, Pracownik socjalny wobec wyzwań aktywnej polityki społecznej, w: Praca socjalna. Ksztatcenie - działanie - konteksty, red. A. Kanios, M. Czechowska-Bieluga, Kraków 2010, s. 94-95.

28 J. Balicki, Rodzina, w: Stownik społeczny, dz. cyt., s. 1118. 
przyczynił się w dużym stopniu do wyłonienia się zasady zrównoważonego rozwoju.

Familiologia w kształtowaniu świadomości osoby wchodzi zatem w zakres antropologii społecznej, etyki małżeńskiej, psychologii prenatalnej i rozwojowej, psychologii rodziny, socjologii rodziny, pedagogiki społecznej, pedagogiki specjalnej, prawa rodzinnego, a nawet tutoringu (indywidualnej opieki kształtującej relację mistrz-uczeń). Wachlarz tych specjalności potwierdza większą profesjonalizację działań w zakresie pomocy społecznej i konieczność opanowania bogatego katalogu umiejętności zawodowych ${ }^{29}$. Zastosowanie wiedzy osób pełniących zawody służące rodzinie na polu wymienionych dyscyplin naukowych ma ukazać szeroki zakres funkcjonowania rodziny, w której dokonująca się socjalizacja jest kluczowa w przyjmowaniu stylów życia i późniejszego zachowania w sferach odnoszących się do wymogów społeczno-ekonomicznych zrównoważonego rozwoju. Wzmocnieniu wartości rodziny odpowiada udoskonalenie funkcji emocjonalno-ekspresyjnej, służącej spełnianiu potrzeb kontaktu psychicznego, który najlepiej mogą ugruntować uwarunkowania rodziny: więź między współmałżonkami oraz między małżonkami a dziećmi ${ }^{30}$. Wraz z odniesieniem do funkcji demograficznej rodziny ta grupa społeczna i instytucja jednocześnie jest zasobem społecznym, bowiem zapewnia ciągłość pokoleń i jest znaczącym czynnikiem kształtowanej kultury.

Funkcję socjalizacyjną i emocjonalno-ekspresyjną wspomagającą rodzinę w przestrzeni pomocy społecznej może wypełniać także facylitator. Atutem takiej osoby jest neutralność w grupie społecznej lub organizacji pomocowej. Pożądane jest, by familiolog posiadał umiejętność stawania się facylitatorem, który w procesach edukacyjnych będzie zabiegał o efektywność w pracy grupy społecznej. Przy tym nie można zapomnieć o skutecznym i adekwatnym do problemu interweniowaniu w kwestiach ważnych dla rozwoju osobowego człowieka. Funkcję emocjonalno-ekspresyjną facylitator realizuje przez ułatwianie komunikacji i dbanie o właściwy proces komunikacyjny pośród osób tworzących rodzinę. W socjalizacji powinien on zmierzać do oddania członkom rodziny

29 M. Ciczkowska-Giedziuń, Ksztatcenie pracowników socjalnych do pracyz rodzina, dz. cyt., s. 71.

30 J. Balicki, Rodzina, w: Stownik społeczny, dz. cyt., s. 1118. 
odpowiedzialności za podejmowane działania. Facylitator nie może wyręczać członków grupy w powierzonych im zadaniach, jego działanie ma zmierzać do nabycia przez jednostki umiejętności samodzielnego rozwiązywania problemów. O ile familiolog, tak jak sam rodzic lub osoba wspomagająca role rodzicielskie, może narzucać swoje rozwiązania - gotowe i sprawdzone, to facylitator może zaproponować metody. Decyzje jednak wyboru metod facylitator pozostawia uczestnikom procesu komunikacyjnego. Rolę facylitatora można więc porównać do stróża czuwającego nad właściwym przebiegiem spotkania, procesu wychowawczego. Jest on także inicjatorem działań, przewodzącym w dyskusji, umiejętnie wycofującą się jednostką, która potrafi w odpowiednim momencie zadać adekwatne do sytuacji pytanie. Celem pracy facylitatora jest czuwanie nad budowaniem przestrzeni swobodnego wypowiadania swoich przekonań w taki sposób, by w rodzinie tworzyła się relacja zaufania i współpracy. Ważną umiejętnością do uskutecznienia tego założenia jest sztuka zareagowania w odpowiednim czasie - tak, by w grupie nie tworzyły się dysfunkcje poszczególnych jednostek. Zadaniem facylitatora jest zatem zachowanie odpowiedniego dystansu i czuwanie nad przebiegiem procesu komunikacyjnego w taki sposób, by można było oddać dominację członkom grupy: w rodzinie rodzicom - budując ich autorytet - lub dzieciom - wzmacniając ich samodzielność, w zależności od specyfiki sytuacji i problemu.

\section{Zakończenie}

Marginalizacja komponentu społecznego w realizacji zrównoważonego rozwoju na rzecz działań wzmacniających trendy ekologiczne uzasadniane w nurtach nieantropocentrycznych etyk środowiskowych stała się jednym z głównych uwarunkowań wyłonienia zasady zrównoważonego rozwoju. Podkreśla ona personalizm chrześcijański i system wartości wpisujący się w nurt funkcjonowania państwa, którego stabilność oparta jest na zastosowaniu systemu podstawowych zasad etyczno-społecznych. Pośród celów zrównoważonego rozwoju w kwestii światopoglądowej wzmocnienie rodziny jako zasobu społecznego powinno dokonywać się w odwołaniu do zasady pomocniczości. Bezdyskusyjnie wskazuje ona na chrześcijańskie założenia antropologii społecznej. 
Mając na uwadze stanowisko Krzysztofa Frysztackiego o pojmowaniu pracy socjalnej jako szczególnej przygody, która wiąże się z trudem z powodu służby ludziom zmarginalizowanym i stygmatyzowanym, należy podkreślić uwagę, że trudność świadczenia pracy socjalnej wzmaga dodatkowo kłopotliwość społeczeństwa w kwestii akceptacji problemów społecznych ${ }^{31}$. Nadinterpretacja komponentu środowiskowego w zrównoważonym rozwoju wydaje się być jedną z wielu kwestii problematycznych życia społecznego, stąd łączenie zróżnicowanych form pomocy społecznej z realizacją celów środowiskowych może służyć tworzeniu uwarunkowań pomocnych rodzinie. Konieczne jest uświadomienie społeczeństwa o potrzebie odrzucenia nieantropocentrycznych nurtów etyk środowiskowych, w ostateczności szkodzących człowiekowi poprzez kreację kultury jemu nieprzyjaznej. Reperkusją tak ujmowanej kultury jest choćby zwiększająca się akceptacja statusu zwierząt w walce o ich prawa, gdy granica człowieczeństwa staje się coraz bardziej płynna, a kategorię osoby rozszerza się o zwierzęta ${ }^{32}$. Przeciwdziałanie nadinterpretacjom biocentrycznym wzmacnia nurt antropocentryzmu umiarkowanego i poprzez takie działanie praca familiologów może być świadczona w szerszym zakresie wraz z celami zrównoważonego rozwoju. Niwelowany jest wówczas deficyt społeczny w realizacji tej koncepcji rozwoju zintegrowanego. W zakresie komponentu społecznego zasady zrównoważonego rozwoju ujmowanego w obszarze pomocy społecznej wymaga się wzmocnienia instytucji rodziny, zwłaszcza na płaszczyznach edukacyjno-wychowawczych. Familiologia staje się dla tych działań odpowiednią propozycją do wzmocnienia profesjonalnie świadczonej pracy socjalnej.

31 K. Frysztacki, Wokót pracy socjalnej. Od koncepcji i teorii do kontekstów empiryczno-aplikacyjnych, Kraków 2019, s. 247-248.

32 M. Gierycz, Europejski spór o człowieka. Studium z antropologiipolitycznej, Warszawa 2017, S. 222. 


\section{Abstrakt}

Wzrost świadomości osoby w aplikacji zasady zrównoważonego rozwoju. Rodzina jako zasób spoteczny

Opracowanie uwydatnia znaczenie komponentu społecznego zasady zrównoważonego rozwoju, która w korelacji z systemem podstawowych zasad etyczno-społecznych utwierdza świadomość rozumianą w nurcie personalizmu chrześcijańskiego. Zabezpieczenie statusu integralnie rozumianego człowieka stanowi podstawę jego praw do życia i rozwoju. W opracowaniu ukaże się najpierw zasadę zrównoważonego rozwoju w kontekście występowania etyk nieantropocentrycznych. Następnie wskaże się pożądany cel aplikacji tego principium etyczno-społecznego: wzrost świadomości osobowej w kontekście realizacji celów zrównoważonego rozwoju. Dla uwydatnienia komponentu społecznego zasady zrównoważonego rozwoju wskaże się rodzinę jako zasób w realizacji polityki społecznej.

Słowa kluczowe: familiologia, facylitacja, praca socjalna, rodzina, zasada zrównoważonego rozwoju, socjologia, tutoring

\section{Abstract}

Increased awareness of the person in the sustainable development principle application. The family as a social resource

The study strengthens the sustainable development principle in social component significance. In correlation with the system of basic ethical and social principles, it confirms the consciousness understood in the current of Christian personalism. Securing the status of an integrally understood man is the basis of his rights to life and development. First, the study will introduce the sustainable development principle in the context of non-anthropocentric ethics. Next, the desired goal of applying this ethical and social principle will be indicated: an increase in personal awareness in the context of achieving the goals of sustainable development. To emphasize 
the social component of the sustainable development principle indicate the family as a resource in the implementation of social policy.

Keywords: familiology, facilitation, social work, family, sustainable development principle, sociology, tutoring

\section{Bibliografia}

Balicki J., Rodzina, w: Stownik społeczny, red. B. Szlachta, Kraków 2004, s. 1117-1124.

Ciczkowska-Giedziuń M., Ksztatcenie pracowników socjalnych do pracyz rodzina, w: Praca socjalna. Ksztatcenie - działanie - konteksty, red. A. Kanios, M. Czechowska-Bieluga. Kraków 2010, s. 71-78.

Czarnecki P.S., Praca socjalna, Warszawa 2013.

Dróżdż M., W poszukiwaniu antropologicznych kontekstów wykluczenia spotecznego. Inspiracje personalistyczne, „Studia Socialia Cracoviensia” 6 (2014), nr 2, s. 83-95.

Fel S., Maltuzjanizm, w: Encyklopedia katolicka, t. XI, Katolicki Uniwersytet Lubelski Jana Pawła II, Lublin 2006, s. 994-995.

Fel S., Marczak Ł., Powstanie i status zasady zrównoważonego rozwoju, „Roczniki Nauk Społecznych” 44 (2016) nr 2, s. 185-205.

Formy świadomości społecznej, red. K. Sztalt, M. Zemło, Lublin 2013.

Franciszek, Laudato si', Watykan 2015.

Frysztacki K., Wokót pracy socjalnej. Od koncepcji i teorii do kontekstów empiryczno-aplikacyjnych, Kraków 2019.

Gałkowski S., Ekologia - przyroda - ochrona środowiska, w: Stownik katolickiej nauki społecznej, red. W. Piwowarski, Warszawa 1993, s. 45-46.

Ganowicz-Bączyk A., Etyka środowiskowa, w: Etyka. Część II. Filozoficzna etyka życia spetnionego, red. S. Janeczek, A. Starościc, Lublin 2016, s. 181208.

Gierycz M., Europejski spór o człowieka. Studium z antropologii politycznej, Warszawa 2017.

Góra M., Środowisko życia człowieka i jego rozwój w kontekście politycznym iśrodowiskowym, „Studia Socialia Cracoviensia” 5 (2013) nr 1, s. 159-170. Kantowicz E., Elementy teorii i praktyki pracy socjalnej, Olsztyn 2001, s. 341. 
Nagórny W., Polityka społeczna a zrównoważony rozwój, „Prace Naukowe AJD. Pragmata Tes Oikonomias" (2011) nr 5, s. 137-146.

Ossowski S., Z zagadnień struktury społecznej, w: S. Ossowski, Dzieła, t. V, Warszawa 2005.

Piwowarski W., Dobro wspólne, w: Stownik katolickiej nauki społecznej, red. W. Piwowarski, Warszawa 1993, s. 41-42.

Prüfer P., Idea rozwoju ludzkiego. Myśl społeczna Kościoła w stużbie rozwoju każdego człowieka i wszystkich ludzi, w: Wobec Boga i człowieka, red. E. Piotrowski, Zielona Góra-Gorzów Wlkp. 2006, s. 189-206.

Szot L., Praca socjalna w polskim systemie pomocy społecznej, w: Aspekty teoretyczne i praktyczne pracy socjalnej wobec przemian i wyzwań spotecznych XXI wieku. Między ksztatceniem a praktyka, t. 2, red. M. Duda, L. Szot, A. Świerczek, Kraków 2017, s. 39-53.

Trafiałek E., Pracownik socjalny wobec wyzwań aktywnej polityki społecznej, w: Praca socjalna. Ksztatcenie - dziatanie - konteksty, red. A. Kanios, M. Czechowska-Bieluga, Kraków 2010, s. 91-100.

Vogt M., Prinzip Nachhaltigkeit. Ein Entwurf aus theologisch-ethischer Perspektive, München 2009.

Vogt M., Retinität: Vernetzung als ethisches Leitprinzip für das Handeln in komplexen Systemzusammenhängen, w: Komplexe adaptive Systeme, red. S. Bornhold, P. H. Feindt Roll, Dettelbach 1996, s. 159-197.

Zrównoważony rozwój - wyzwania globalne. Podręcznik dla uczestników studiów doktoranckich, red. P. Trzepacz, Kraków 2012.

Żurko M., Świadomość osoby, w: Formy świadomości społecznej, red. K. Sztalt, M. Zemło, Lublin 2013, s. 69-89. 